\title{
Socio-economic and policy implications of multi-stressed rivers : A European perspective
}

\author{
P. Koundouri ${ }^{1,2,3, *}$, E. Akinsete ${ }^{3,4}$, and S. Tsani ${ }^{1,3}$ \\ ${ }^{1}$ School of Economics, Athens University of Economics and Business, Greece \\ ${ }^{2}$ Grantham Research Institute, London School of Economics and Political Science, UK \\ ${ }^{3}$ International Center for Research on the Environment and the Economy (ICRE8), Athens, \\ Greece \\ ${ }^{4}$ School of Applied Social Studies, Robert Gordon University, Aberdeen, UK \\ *Corresponding author, e-mail: pkoundouri@aueb.gr
}

\begin{abstract}
Recent policy developments have taken into account the simultaneous effect of many individual pressures on rivers. At the European level, several directives and measures have addressed this issue while aligning with the goals of sustainable water management. In particular, the need to assess the total economic value of water resources and the impact of the associated policies has been well understood. This chapter discusses the EU policies on water resource management and multiple stressors acting on the river basins, with emphasis on the design and implementation of the Water Framework Directive (WFD) and on its socioeconomic and environmental dimensions. The chapter also discusses methodological approaches to assess the total economic value of water-related services and how to implement the ecosystem services approach to reach the WFD goals. Our analysis indicates that despite significant steps towards sustainable management of water resources in the EU and despite considering the impact of multiple stressors in river basins, it is still necessary to improve policy design and implementation. Appropriate supportive methodologies must be developed that consider the socio-economic and environmental dimensions of water policies.
\end{abstract}

Key words: Policy, Water Framework Directive, EU, Ecosystem Services, Multiple Stressors, Sustainable Water Management, River Basin 


\subsection{Introduction}

Rivers have been described as the "arteries of our planet" (WWF, 2017) acting as habitats to freshwater biodiversity, and also providing vital services such as water, food and energy supply. Rivers form an essential part of the global water cycle, supporting irrigation and drainage, whilst enabling the distribution of dissolved and particulate materials. Despite the importance of the world's waterways, they are under pressure from multiple stressors as a consequence of industrialization, urbanization, changes in land use, and associated human activity such as water abstraction, pollution, or geomorphological alterations (Vörösmarty et al., 2010; UN Water, 2013).

Many studies examined the effects of individual stressors on the chemical and ecological status of water bodies. However, there is limited knowledge on the cumulative and interactive effects of multiple stressors (Navarro-Ortega et al, 2015). In many cases, these stressors have the potential to create socio-economic impacts to the communities using the resource, thereby making vital the effective and sustainable management of natural resources (Ludwig et. al., 2011). This dearth of knowledge has led to a paradigm shift in the approach towards multiple stressors, applying holistic systems thinking to resource management, at various scales from local to global (Vörösmarty et al., 2010; Voulvoulis et al, 2016).

Acknowledging the importance of addressing the multiple stressors on rivers, recent policy developments have attempted to incorporate integrated measures into water resources and river basin management. In the EU, member states have agreed to a series of regulations and directives that aim at the sustainable management of water resources and that explicitly consider the relevance of multiple stressors impacting on the river basins. From a methodological perspective, such policies must develop an integrated approach to river basin evaluation and management, one that incorporates the total economic, social and environmental value of water, as well as the impact of the implemented measures.

\subsection{Sustainable Development Goals and EU water policies}

On a global scale, decision makers are in constant pursuit of effective frameworks and policies to support sustainable water management, balancing ecosystem protection and use of resources by humans. Despite this, Vörösmarty et al. (2010) assert that water resource 
management at global level remains fragmented. The concept of Global Water Governance was coined to address this problem (Fig. 19.1; Rogers and Hall, 2003; Cooley et al, 2013).

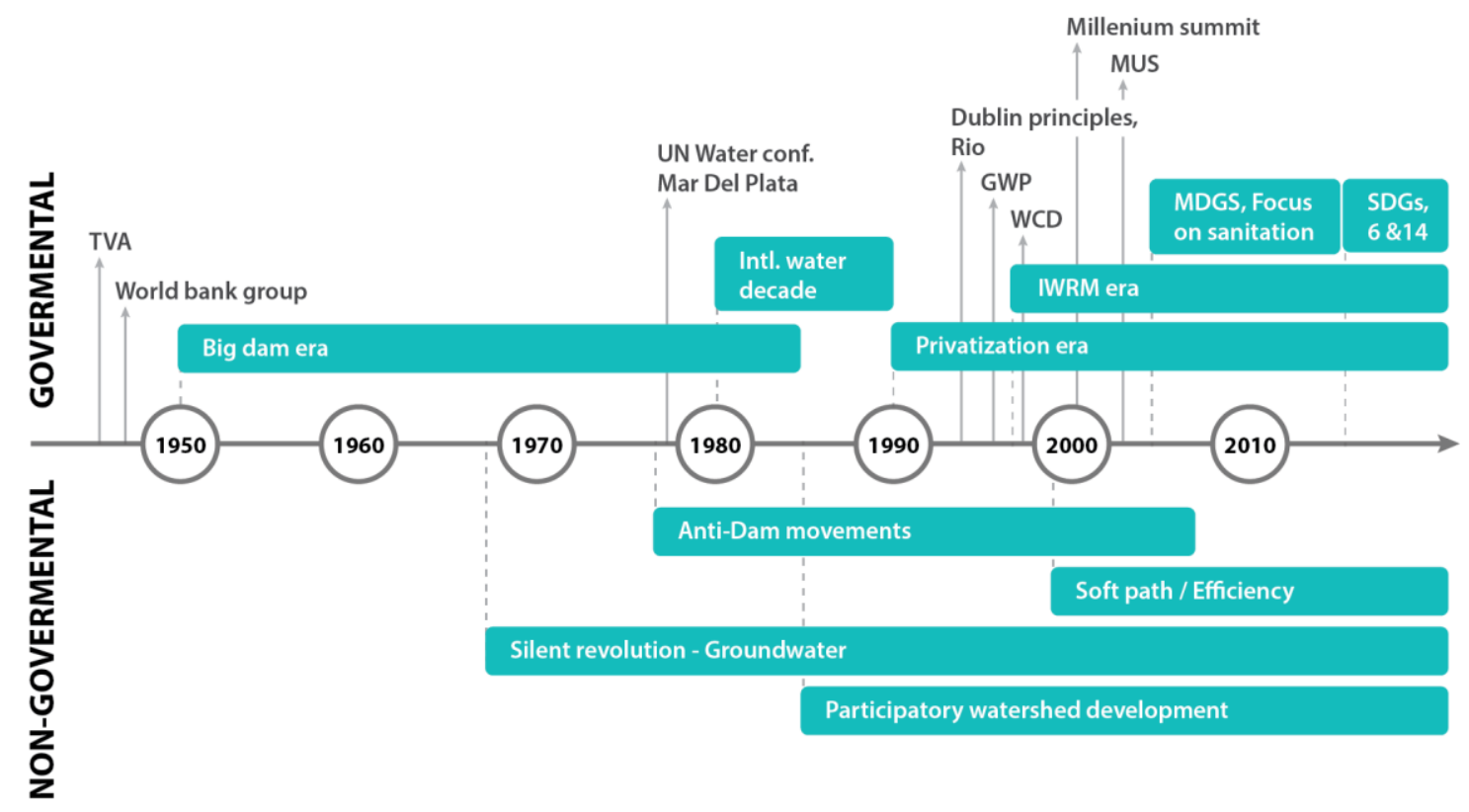

Figure 19.1: Timeline of the Global Water Governance (Adapted from Cooley et al, 2013)

The United Nations (UN) emphasize the fact that sustainable water resource management and sustainable development are inextricably linked, and that the former is a prerequisite for the latter. They recognize sustainable water management as a social, economic and political challenge, and propose the integration of strategies to manage not only water, but also land and living resources, as well as setting targets at different scales (United Nations, 2003; 2016). In light of this, 2015 saw the UN set out the Sustainable Development Goals (SDGs) as a follow up to the Millennium Development Goals (MDGs) (Fig. 19.2). 

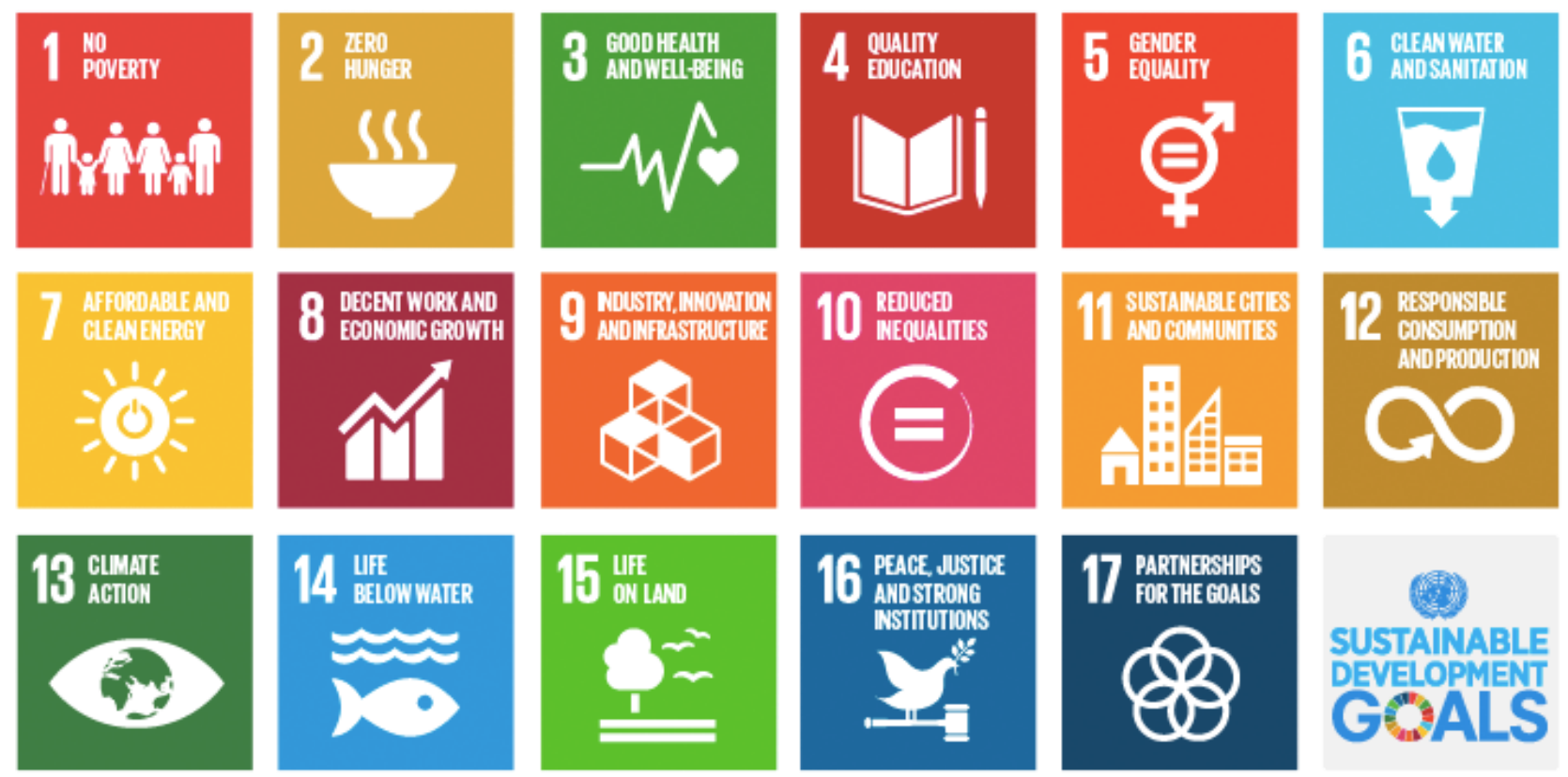
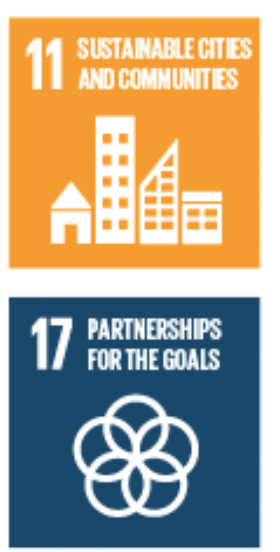
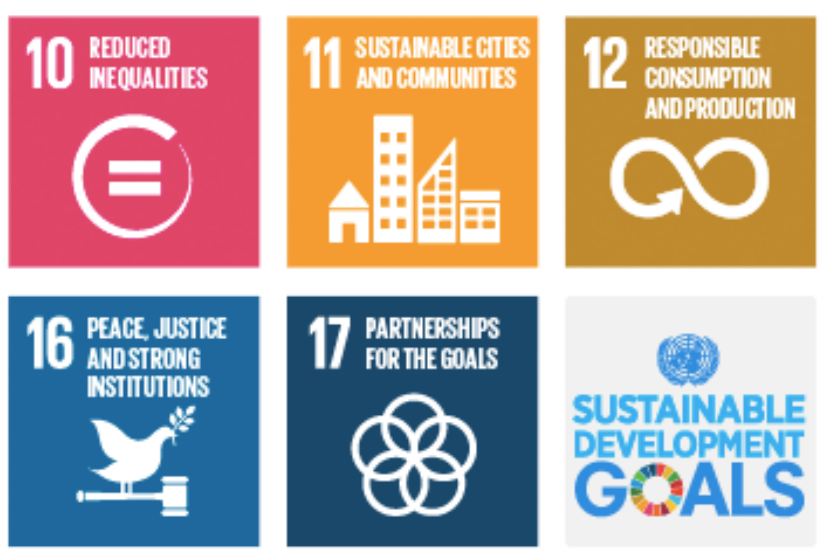

Figure 19.2: The UN Sustainable Development Goals (Source: UN, 2016)

The 17 SDGs include two goals specifically focused on water-related issues: SDG number 6 (Clean Water and Sanitation) and 14 (Life Below Water). In addition to these goals, there are also two water-related cross-cutting themes as set out by the Open Working Group on SDGs, namely "Sustainable management of oceans and coastal areas" and "Water and sanitation" (Sustainable Development Solutions Network, 2015). In order to monitor and assess the implementation of the SDGs, the Inter-Agency and Expert Group on SDG Indicators (IAEGSDGs) has developed a list of 232 SDG indicators. The indicators cover all 17 SDGs and reflect various scales from regional to global as illustrated (IAEG-SDGs, 2017). Figure 19.3 indicates the overall performance of a cross section of countries (GLOBAQUA ${ }^{1}$ case study countries) in relation to the 17 SDGs following the first round of reporting against the SDG indicators. Countries are scored based on a colour coded rating system where 'Green' indicates SDG achievement (i.e. all indicators under the goal have been rated green), while yellow, amber and red indicate increasing distance from SDG achievement. Overall the countries are performing to varying degrees of efficiency across all SDGs; however, when it comes to the water related SDGs, performance is generally poor. With the exception of Serbia, which achieved a green rating under SDG 6, all other indicated countries achieved mostly yellow ratings. Under SDG 14, most countries received a red rating excluding Croatia

\footnotetext{
${ }^{1}$ EU Funded GLOBAQUA Project aims to identify the prevalence of, and interaction between, stressors under water scarcity http://www.globaqua-project.eu/en/home/
} 
which received an amber rating and Serbia which failed to receive a rating due to insufficient data.

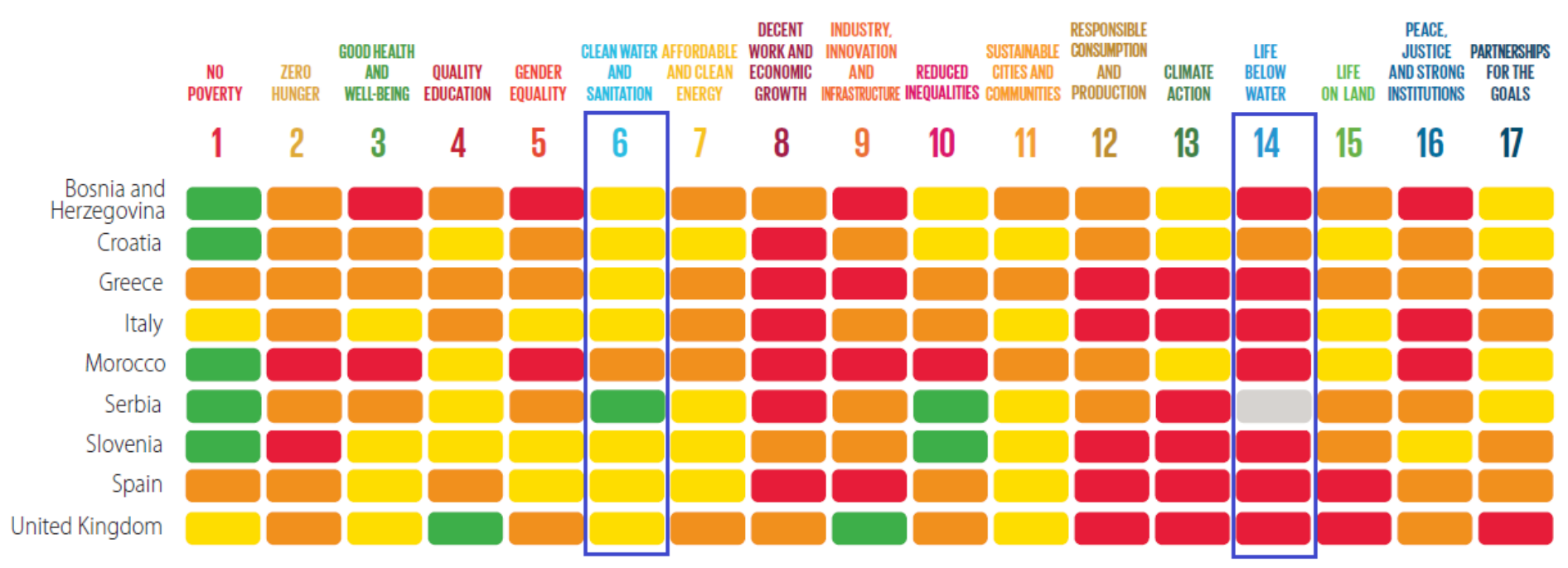

Figure 19.3: SDG Index Dashboard with a spotlight on GLOBAQUA ${ }^{2}$ Case Study Countries highlighting performance on water-related SDGs 6 and 14 (Adapted from SDSN, 2015).

Given that the SDGs address the full spectrum of developmental issues, the UN High Level Panel on Water (HLPW) was convened in 2016 specifically to "ensure availability and sustainable management of water and sanitation for all, as well as to contribute to the achievement of the other SDGs that rely on the development and management of water resources" (HLPW, 2016). The HLPW is geared towards motivating effective actions that will generate long-term integrated impacts, as well as promoting and mobilizing efforts to finance these actions. The HLPW is underpinned by four cross-cutting themes:

i. Considering sustainable water resource management as everyone's responsibility

ii. Sustainable access to water services for all

iii. Efficient and holistic valuation of water as a resource

iv. Investment in water for the long run

Working along the same lines, the European Commission (EC) has put in place several frameworks and policies to manage water resources across the continent by regulating the chemical and ecological status of European water bodies. These directives include: the

\footnotetext{
${ }^{2}$ EU Funded GLOBAQUA Project aims to identify the prevalence of, and interaction between, stressors under water scarcity http://www.globaqua-project.eu/en/home/
} 
Nitrates Directive (1991), the Urban Wastewater Treatment Directive (1991), the Plant Protection Products Directive (1991), the Directive for Integrated Pollution and Prevention Control (1996), the Biocides Directive (1998) and the Groundwater Directive (2006) (see European Commission, 2017). The earliest of these policies, the 1980 Drinking Water Directive (Directive 80/68EEC), regulated levels of pollution in water bodies by defining standards for toxic chemicals as well as for substances that cause health hazards and occur in drinking water. In 1998, the 1980 directive was replaced by the New Drinking Water Directive (Directive 98/83/EC), (EC, 1980; 2017), still limited in the sense that approached multiple stressors (pollutants, population density, etc.) in isolation. It was not until the introduction of the Water Framework Directive (WFD, Directive 2000/60/EC) in 2000 that a genuine effort was made to consider the quality of freshwater ecosystems holistically, and address the simultaneous impact of multiple stressors with complex environmental, social and economic interactions.

\subsection{The Water Framework Directive: Design, implementation and assessment}

The core objective of the WDF was to create an EU-wide integrated framework to manage water resources including inland surface waters, transitional waters, coastal waters and ground waters, with the aim of achieving "Good Ecological and Chemical Status" by 2015. It addresses three core elements of aquatic ecosystems, namely: water quality, water quantity and aquatic habitat.

The WFD was meant to depart from the earlier traditional water resource management approaches, which targeted individual stressors and largely neglected stressors acting simultaneously on the water body. For the first time, both the chemical status (e.g. pollutants) and the ecological status (e.g. biodiversity) are taken into consideration to determine the quality of a given water body. The WFD is currently in its second management cycle, which is due to run until 2021, with a third cycle anticipated to run until 2027 (Voulvoulis et al, 2016).

Another innovative aspect of the WFD is its recognition of the importance of socioeconomics in achieving the environmental objectives. Under articles 5 (Characteristics of the river basin district, review of environmental impact of human activity and economic analysis of water use) and 9 (Recovery of costs for water services), the WFD lays emphasis on 
economic assessment and tools. It does so not only as a means to justify the cost effectiveness of chosen measures but also the total cost recovery (environmental, financial and resource costs) of water services by all users (Koundouri and Davila, 2015).

In implementing the WFD, member states are required to:

- identify the river basins in their national territory and assign them to individual river basin districts (RBDs)

- characterize the baseline status of RBDs, including pressures, impacts and economics of water uses as well as protected areas

- intercalibrate the national systems to assess the ecological status

- identify a programme of cost-effective measures to achieve the WFD's environmental objectives

- publish River Basin Management Plans (RBMPs) for each RBD

- implement water pricing policies that enhance the sustainability of water resources

- put the developed programme of measures into operation

The WFD essentially presents a framework for the effective management of water bodies and poses few specific obligations. Rather, it is down to member states to transpose the WFD into national laws and to outline specific measures within their RBMPs. In transboundary RBDs, the involved countries are required to work closely together to develop a common RBMP (even in cases where not all countries are EU member states). This is the case of the Sava River for instance. The RBDs constitute the functional units of the WFD and represent the scale at which all planning and management actions take place. The RBMP serves as the core planning document in terms of the implementation of the WFD. The RBMPs further provide a legislative link to other water-related objectives within other Directives such as the Urban Wastewater Treatment Directive, the Drinking Water Directive, the Habitats Directive, the Nitrates Directive etc. Thereby the WFD embraces an integrated approach to sustainable water resource management at river basin scale, by taking into consideration the entire ecosystem including land uses.

Each RBD is to conduct an economic analysis in accordance with Annex III of the WFD. The analysis must consider the major drivers and pressures in the RBD, and the contribution of water uses in the recovery of costs consistent with the "polluter pays" principle, in order to 
inform the selection of the most cost-effective set of measures for balancing water demand and supply. Based on this economic analysis, member states are required to take into account the total cost recovery of water services (EC, 2002).

In 2001, the member states, Norway and the EC enacted a Common Implementation Strategy (CIS; EU 2010) which aims at facilitating the implementation of the WFD.

The CIS is founded on four core elements:

i. Information sharing and raising awareness,

ii. Developing guidance documents

iii. Establishing information management system

iv. Integrated testing in pilot river basins

The CIS process is organized on three levels:

- Strategic Coordination Group: is responsible for managing the CIS, and provides a forum for the EC, member states, candidate countries and stakeholders to evaluate progress and raise issues

- Technical Working/Drafting Groups: as technical experts, are responsible for the development of guidance documents and presenting 'best practice' tools, approaches and solutions in relation to WFD implementation

- Water Directors: are responsible for final decisions on strategy development and guidance

2015 marked the end of the first cycle of the WFD, but only $53 \%$ of surface water within the EU reached the goal of Good Ecological Status. Furthermore, the number of water bodies reaching Good Ecological Status had increased only by 10\% (van Rijswick and Backes, 2015; Voulvoulis et al, 2016). The low effectiveness of the policy has been largely attributed to poor implementation; in particular, the EC (2007) noted that there were shortcomings in the economic analysis of most member states. Aspects such as cost recovery are only partially implemented in households and industry, and even not so within the agricultural sector. In addition, very few member states have carried out a transparent exercise when it comes to the cost recovery of the water resource (Koundouri and Davila, 2015). Refining not just the adopted economic instruments but also a rigorous implementation of the entire socioeconomic sphere of the WFD is crucial to ensure an integrated approach (environmental, social and economic). 


\subsection{The WFD Programmes of Measures as a multiple-pressures targeting tool}

Each RBMP sets out specific Programmes of Measures (PoMs) in order to achieve good chemical and ecological status within each RBD. The PoMs are developed to target the specific combination of pressures faced within respective RBDs. While the RBMP provides an overview of the baseline and the strategic approach to achieve the objectives of the WFD, the set of PoMs is the tool that provides the legislative impetus to mandate action towards improving water quality. The design, implementation and evaluation of the PoMs constitute an iterative process to be reviewed and adapted periodically. Article 11 of the WFD sets out two types of measures required within the RBMPs:

- Basic measures: derived from other directives, such as The Habitat Directive, The Nitrates Directive, or The Urban Wastewater Treatment Directive.

- Supplementary measures: additional measures adopted invariably at a local scale to further improve water quality where the basic measures prove insufficient.

As such, the PoMs consist of both technical and non-technical instruments for the control of pollution, maintenance of environmental standards and development of capacity and awareness. Further, economic instruments, such as water pricing and taxation schemes, must follow the "polluter pays" principle (EC, 2000; Kavanagh and Bree, 2009; EEA, 2014).

A key aspect of developing the PoMs is to identify major drivers and pressures in each RBD, and to assess the performance of proposed measures. As part of this requirement, an economic analysis including all the relevant information and details as underlined in Annex III needs to be conducted. Moreover, according to the "polluters pay" principle, the economic analysis must include the contribution of water uses in the cost recovery, to assist in the identification of cost-effective measures. Here it should be noted that the socio-economic appraisal of the measures and the identification of the most appropriate ones is a challenging task. Certain aspects of the measures may be addressed through relatively well-established methods, such as the evaluation of the loss due to restrictions on water abstractions through "water demand curves" (Reynaud, 2015) or the assessment of regulatory measures on specific investments through engineering costs. But most frequently, appraisal of measures an ad hoc assessment in the context where the measures are taken. 
To make this appraisal process more transparent, and thereby explicitly link the various pressures acting on the RBD and the measures to address them, Pistocchi et al (2016) propose an integrated assessment framework which sets out 5 steps:

1. Understanding how different pressures affect the status of water bodies

2. Identifying the relevant pressures to be addressed through measures

3. Evaluating reduction targets for the relevant pressures

4. Designing management measures

5. Simulating scenarios of measure implementation

In its latest evaluation report, the EC (2015) noted that the majority of the member states implemented only basic measures, the most common of which include:

- Construction or upgrade of urban waste water treatment (reported by 19 member states)

- Reduction of nutrient pollution in agriculture (reported by 16 member states)

- Hydromorphological measures such as improvements to river continuity (reported by 16 member states)

- Capacity development (reported by 15 member states)

- Measures to protect drinking water (reported by 15 member states)

The combination of measures adopted with the various RBMPs and their presentation varies between RBDs. While some RBMPs present broad stroke measures, generally citing directives that must be enforced, others provide detailed descriptions of the PoMS and set out specific actions with varying degrees of detail regarding the scope and location of the measures (Koundouri and Davila, 2015). Table 19.2 sets and contrasts a number of PoMs adopted within different RBMPs. 
Table 19.2: PoMs to address multiple pressures as a result of agriculture and hydromorphology outlined within GLOBAQUA ${ }^{3}$ Case Study RBDs Adige (Italy), Ebro (Spain), Anglian (UK) and Souss Massa (Morocco). Source: Koundouri, Akinsete and Souliotis (2017)

\begin{tabular}{|c|c|c|c|c|}
\hline & \multicolumn{3}{|c|}{ PoMs addressing agricultural pressures } & \multirow{2}{*}{\begin{tabular}{|l|} 
PoMs addressing \\
hydromorphological pressures \\
Technical measures \\
\end{tabular}} \\
\hline & Technical measures & Economic instruments & Non-technical measures & \\
\hline $\begin{array}{l}\text { Adige } \\
\text { RBD }\end{array}$ & $\begin{array}{l}\text { - Reduction/modification of } \\
\text { fertilizer application } \\
\text { - Reduction/modification of } \\
\text { pesticide application } \\
\text { - Change to low-input farming } \\
\text { (e.g. organic farming practices) } \\
\text { - Hydro morphological measures } \\
\text { leading to changes in farming } \\
\text { practices } \\
\text { - Multi-objective measures (e.g. } \\
\text { crop rotation, creation of } \\
\text { enhanced buffer, zones/wetlands } \\
\text { or floodplain management) } \\
\text { - Technical measures for water } \\
\text { saving in agriculture }\end{array}$ & $\begin{array}{l}\text { - Water pricing } \\
\text { specifications for } \\
\text { irrigators }\end{array}$ & $\begin{array}{l}\text { - Codes of agricultural practice } \\
\text { - Farm advice and training } \\
\text { - Certification schemes } \\
\text { - Specific projects related to } \\
\text { agriculture } \\
\text { - Environmental permitting and } \\
\text { licensing }\end{array}$ & $\begin{array}{l}\text { - Habitat restoration - building } \\
\text { spawning and breeding areas } \\
\text { - Restoration of bank structure } \\
\text { - Setting minimum ecological flow } \\
\text { requirements }\end{array}$ \\
\hline
\end{tabular}

${ }^{3}$ EU Funded GLOBAQUA Project aims to identify the prevalence of, and interaction between, stressors under water scarcity http://www.globaqua-project.eu/en/home/ 


\begin{tabular}{|c|c|c|c|c|}
\hline $\begin{array}{l}\text { Anglian } \\
\text { RBD }\end{array}$ & $\begin{array}{l}\text { - Reduction/modification of } \\
\text { fertilizer application } \\
\text { - Reduction/modification of } \\
\text { pesticide application } \\
\text { - Hydromorphological measures } \\
\text { leading to changes in farming } \\
\text { practices } \\
\text { - Measures against soil erosion } \\
\text { - Multi-objective measures (e.g. } \\
\text { crop rotation, creation of } \\
\text { enhanced buffer zones/wetlands } \\
\text { or floodplain management) } \\
\text { - Technical measures for water } \\
\text { saving in agriculture }\end{array}$ & $\begin{array}{l}\text { - Compensation for land } \\
\text { cover } \\
\text { - Co-operative agreements }\end{array}$ & $\begin{array}{l}\text { - Codes of agricultural practice } \\
\text { - Farm advice and training } \\
\text { - Raising awareness of farmers } \\
\text { - Measures increase knowledge } \\
\text { for improved decision-making } \\
\text { - Specific action } \\
\text { plans/programmes } \\
\text { - Land use planning } \\
\text { - Specific projects related to } \\
\text { agriculture and Environmental } \\
\text { permitting and licensing }\end{array}$ & $\begin{array}{l}\text { - Fish ladders } \\
\text { - Habitat restoration, building } \\
\text { spawning and breeding areas } \\
\text { - Sediment/debris management } \\
\text { - Removal of structures: weirs, } \\
\text { barriers, bank reinforcement } \\
\text { - Restoration of bank structure } \\
\text { - Operational modifications for } \\
\text { hydropeaking } \\
\text { - Inundation of flood plains } \\
\text { - Restoration of degraded bed } \\
\text { structure }\end{array}$ \\
\hline $\begin{array}{l}\text { Ebro } \\
\text { RBD }\end{array}$ & $\begin{array}{l}\text { - Reduction/modification of } \\
\text { fertiliser application } \\
\text { - Reduction/modification of } \\
\text { pesticide application } \\
\text { - Change to low-input farming } \\
\text { (e.g. organic farming practices) } \\
\text { - Hydro morphological measures } \\
\text { leading to changes in farming } \\
\text { practices } \\
\text { - Multi-objective measures (e.g. } \\
\text { crop rotation, creation of } \\
\text { enhanced buffer zones/wetlands } \\
\text { or floodplain management) } \\
\text { - Technical measures for water } \\
\text { saving }\end{array}$ & $\begin{array}{l}\text { - Compensation for land } \\
\text { cover } \\
\text { - Water pricing } \\
\text { specifications for } \\
\text { irrigators } \\
\text { - Fertilizer taxation }\end{array}$ & $\begin{array}{l}\text { - Additions regarding the } \\
\text { implementation and enforcement } \\
\text { of existing EU legislation } \\
\text { - Controls } \\
\text { - Institutional changes } \\
\text { - Codes of agricultural practice } \\
\text { - Farm advice and training } \\
\text { - Raising awareness of farmers } \\
\text { - Measures to increase knowledge } \\
\text { for improved decision-making } \\
\text { - Zoning (e.g. designating land } \\
\text { use based on GIS maps) } \\
\text { - Specific action } \\
\text { plans/programmes } \\
\text { - Land use planning } \\
\text { - Environmental permits/licenses } \\
\text { - Others (e.g. new water supply } \\
\text { infrastructure) }\end{array}$ & $\begin{array}{l}\text { - Fish ladders } \\
\text { - Bypass channels } \\
\text { - Habitat restoration, building } \\
\text { spawning and breeding areas } \\
\text { - Sediment/debris management } \\
\text { - Removal of structures: weirs, } \\
\text { barriers, bank reinforcement } \\
\text { - Reconnection of meander bends } \\
\text { or side arms } \\
\text { - Lowering of river banks } \\
\text { - Restoration of bank structure } \\
\text { Setting minimum ecological flow } \\
\text { requirements } \\
\text { - Operational modifications for } \\
\text { hydropeaking } \\
\text { - Inundation of flood plains } \\
\text { - Construction of retention basins } \\
\text { - Reduction or modification of }\end{array}$ \\
\hline
\end{tabular}




\begin{tabular}{|c|c|c|c|c|}
\hline & & & & $\begin{array}{l}\text { dredging } \\
\text { - Restoration of degraded bed } \\
\text { structure } \\
\text { - Remeandering of formerly } \\
\text { straightened water courses } \\
\text { - Other (restoration of transitional } \\
\text { and/or coastal waters) }\end{array}$ \\
\hline $\begin{array}{l}\text { Souss } \\
\text { Massa } \\
\text { RBD }\end{array}$ & $\begin{array}{l}\text { - Reduction/modification of } \\
\text { fertiliser application } \\
\text { - Reduction/modification of } \\
\text { pesticide application } \\
\text { - Change to low-input farming } \\
\text { (e.g. organic farming practices) } \\
\text { - Hydro morphological measures } \\
\text { leading to changes in farming } \\
\text { practices } \\
\text { - Multi-objective measures (e.g. } \\
\text { crop rotation, creation of } \\
\text { enhanced buffer zones/wetlands } \\
\text { or floodplain management) } \\
\text { - Technical measures for water } \\
\text { saving }\end{array}$ & $\begin{array}{l}\text { - Compensation for land } \\
\text { cover } \\
\text { - Water pricing } \\
\text { specifications for } \\
\text { irrigators } \\
\text { - Fertilizer taxation }\end{array}$ & $\begin{array}{l}\text { - Additions regarding the } \\
\text { implementation and } \\
\text { enforcement of existing EU } \\
\text { legislation } \\
\text { - Controls } \\
\text { - Institutional changes } \\
\text { - Codes of agricultural practice } \\
\text { - Farm advice and training } \\
\text { - Raising awareness of farmers } \\
\text { - Measures to increase knowledge } \\
\text { for improved decision-making } \\
\text { - Zoning (e.g. designating land } \\
\text { use based on GIS maps) } \\
\text { - Specific action } \\
\text { plans/programmes } \\
\text { - Land use planning } \\
\text { - Environmental permitting and } \\
\text { licensing } \\
\text { - Others (e.g. new water supply } \\
\text { infrastructure) }\end{array}$ & $\begin{array}{l}\text { - Fish ladders } \\
\text { - Bypass channels } \\
\text { - Habitat restoration, building } \\
\text { - spawning and breeding areas } \\
\text { - Sediment/debris management } \\
\text { - Removal of structures: weirs, } \\
\text { barriers, bank reinforcement } \\
\text { - Reconnection of meander bends } \\
\text { or side arms } \\
\text { - Lowering of river banks } \\
\text { - Restoration of bank structure } \\
\text { - Setting minimum ecological flow } \\
\text { requirements } \\
\text { - Operational modifications for } \\
\text { - hydropeaking } \\
\text { - Inundation of flood plains } \\
\text { - Construction of retention basins } \\
\text { - Reduction or modification of } \\
\text { dredging } \\
\text { - Restoration of river bed structure } \\
\text { - Remeandering of formerly } \\
\text { straightened water courses } \\
\text { - Other (restoration of transitional } \\
\text { and/or coastal waters) }\end{array}$ \\
\hline
\end{tabular}




\subsection{Economic valuation of water resources: An ecosystem services approach}

The socio-economic aspects of the WFD are put at the core of the water management to achieve its environmental and ecological objectives. Indicative of this is the requirement set by the WFD of application of economic principles, approaches and instruments at $\mathrm{RBD}^{4}$. An important feature of this Directive is the recovery of total economic cost of water services by all users, what involves identifying and quantifying all costs, including financial, resource and environmental. Financial costs represent the costs of water provision and management, resource costs are associated with water over extraction, and environmental costs can be associated with the loss caused by degraded water quality.

For correct identification and quantification, the costs associated to water provision and use must be linked to different water uses for different sectors, such as households, industry and agriculture. While financial costs may be easily quantified, resource and environmental costs are much harder to estimate. Here the concepts of ecosystem services and Total Economic Value (TEV), as discussed in the following section, can prove useful.

A key challenge is that these costs cannot be expressed in pure monetary or market values. Thus, it is necessary to consider the total economic value of water resources and aquatic ecosystem services, considering the value they bring to society and the costs of their protection or restoration. These are necessary steps in order to evaluate the sustainability, balance and equity of water use.

The ecosystem services approach puts emphasis on the functions and provisions of the ecosystems to humans both in terms of services (such as recreation and leisure) or goods (provision of food, water, etc.). The approach, thus, consists on identifying and understanding the total ecosystem value, as well as the links among actions that affect the functions and the balance of the ecosystem. In the case of river basin management this would regard, for instance, decision on whether to utilize the water and on the effects this decision would have on the different economic sectors and stakeholders. Subsequently, the decision on the

\footnotetext{
${ }^{4}$ See Article 5 "Characteristics of the river basin district, review of environmental impact of human activity and economic analysis of water use", Article 9 "Recovery of costs for water services", Article 11 "Program of measures", and Annex III "Economic analysis".
} 
utilization of water may generate income for some stakeholders while it may put pressure on the income of others.

According to the TEV of Ecosystems and Biodiversity initiative (TEEB, 2010) ecosystem services can be grouped in the following categories: Provisioning services, Regulating services, Habitat services and Cultural services. While some of the ecosystem services and goods can be associated to market-derived prices, many other cannot. In many cases, the value of ecosystems is associated to their intrinsic existence, and not directly associated to their actual use. The TEV approach consists on identifying and quantifying all types of values that an ecosystem can provide.

The method estimates the use and non-use values of the ecosystem services. The use values are based on the actual use of the environment and consist on three basic categories, namely: i) direct use value, e.g. water irrigation costs in agriculture, ii) indirect use value, e.g. water purification or natural hazard mitigation and iii) option value, e.g. potential future uses of water (direct or indirect). The non-use values are associated to the intrinsic existence of the ecosystem and include value categories like: i) bequest, i.e. valuing the fact that an ecosystem will be passed on to future generation, ii) existence, i.e. the value of the existence of the ecosystem as it stands, and iii) altruistic, i.e. valuing the fact that an ecosystem can be enjoyed by other people in the community.

The ecosystem services and TEV approach can be employed in an integrated framework of valuation of water related services in a way that can ensure consistency with the economic principles of the WFD. As discussed in Koundouri et al. (2016) the approach can be summarized in the following steps:

i) socio-economic characterization of the area in question

ii) assessment of the current recovery of water use cost

iii) identification and suggestion of appropriate PoMs for sustainable water management over space and time

In the first step of this approach, the socio-economic importance of water-related services is examined across the various economic sectors. Water use can be examined at sectoral level (i.e. residential, industrial, agricultural, etc.) to identify the socio-economic drivers and pressures that affect the water status, both quantitative and qualitative. Socio-economic data 
are analysed to assess the nature and the importance of water uses and services and to construct a baseline scenario against which alternative scenarios can be compared. At this step the impact of evolving socio-economic drivers on water pressures can be examined. For this it is important to understand the evolution path of core parameters such as trend variables (e.g. changes in economic and population growth), risk and uncertainty variables (e.g. changes in social values), and policy variables (e.g. planned investments). The information required at this stage is similar to the information that EU member states report in the context of the WFD.

The second step assesses the recovery of water use cost, identifying and monetizing the financial, resource, and environmental costs of water use. Financial costs refer to operational, administrative and maintenance costs and investment costs for water supply, sewerage and irrigation companies. Resource costs reflect current and future costs as resulting from the overexploitation of water-related resources beyond the rate of natural replenishment. The cost of the development of a backstop technology as a means to cover water demand and mitigate scarcity issues can be used as an approximation (Koundouri, 2014). The environmental costs refer to those associated with the reduction of water ecosystem quality, which in turn leads to a decrease in the capacity of water-related resources to provide goods and services.

Several methodological approaches can be employed for the valuation of the environmental costs, entailing techniques to estimate the TEV of water resources across the various economic sectors, and the willingness to pay for the conservation of water resources of all affected individuals. The main alternatives can be summarized as follows:

1. Revealed Preference Methods: Observing the behavior of the public in an actual market to elicit the value humans place on impacts stemming from changes in the circumstances. Commonly used approaches include Hedonic Pricing Method, Travel Cost Method, Averting Behavior and Preventive Expenditure methods (see Garrod \& Willis, 1999; Pearce et al., 2006; Venkatachalam, 2004).

2. Stated Preference Methods: Survey-based approaches to elicit individual preferences. Popular approaches here include Contingent Valuation Method, Choice Modelling and Choice Experiments.

3. Benefit Transfer: Using estimates from primary studies undertaken in study sites similar to the policy site. It is extensively used for local, national and global 
ecosystem assessments (e.g. EEA, 2010; TEEB, 2010) and it is often preferred because it is a fast and cheap method.

After estimating the total cost of water related services, it is necessary to identify who bears the costs of water services across the various economic sectors. This can be approximated by the revenues of water companies from each sector. By using these revenues and the total cost of water services, the current level of water cost recovery can be estimated. Then, alternative cost recovery options can be identified, the choice among which depend on the socioeconomic and institutional conditions in water supply and pricing 5 . Alternatives include market pricing, tradable permits, quotas, taxes/subsidies, educational and awareness campaigns, voluntary agreements and legal instruments.

The last step identifies the sustainable policies related to water management over time and space, according to the WFD. The identification of the most cost-effective measures should be coupled here with a long-run Cost-Benefit Analysis (CBA) in order to avoid disproportionality issues in the examined policy alternatives. In the case of water management packages, they can be characterised as disproportionate if: i) good water status achievement impacts negatively on the status of the wider environment and the human activities and ii) the beneficial outcome of good water status cannot be achieved by other means. In the case of disproportionality, less stringent objectives and time derogations from the original plan can be allowed.

The package of measures can be classified as sustainable if the Net Present Value (NPV) is positive, where:

$$
N P V=-\sum_{t=0}^{N} \frac{K_{t}}{(1+r)^{t}}+\sum_{t=0}^{N} \frac{B_{t}-C_{t}}{(1+r)^{t}}
$$

with $K_{t}$ : construction cost, $B_{t}$ : benefits, $C_{t}$ costs and $r$ the discount rate.

One of the most challenging issues in long-term CBA is selecting the appropriate discount rate. One way to address this issue is to use a declining discount rate that puts emphasis on the long-term rather than on the short-term impact of measures on social welfare (see Gollier et al. 2009, Koundouri 2009).

\footnotetext{
${ }^{5}$ To ensure efficiency the selected option should ensure that marginal TEV equals marginal cost.
} 


\subsection{Concluding remarks}

The WFD is undoubtedly a major policy advancement towards sustainable water management in the EU, which even aligns with the UNs SDGs. The directive can deliver considerable socio-economic and environmental benefits, in particular by considering multiple stressors within a river basin. Nevertheless, the nature (whether positive or negative) and the magnitude of the effects cannot be estimated straightforwardly and is not independent of the design and the implementation of the associated policies and measures. In order to obtain a full socio-economic and environmental characterisation of the policies and their effects, appropriate methodologies need to be developed that consider the social, economic and environmental effects of water related policies. Into this direction, TEV and ecosystem services approaches prove useful.

From a policy design and implementation perspective, it may be argued that the great expectations that came with the WFD have not yet been fully realised as a result of the poor interpretation or implementation of the foreseen measures. The directive is coupled with administrative challenges while performance indicators, better characterisation (for instance more complete analysis of the pressures and the impacts in the river basins) or improved monitoring may be required so as to improve the performance and participation of member states. More integrated approaches could make considerable strides in improving some of the observed shortcomings of the WFD implementation and assessment, particularly as it pertains to the PoMs and how they target multiple stressors.

Interdisciplinarity emerges as an additional essential component, not only in WFD design, but also in impact assessment. An interdisciplinary approach is important to address complex issues of water management, but also to make the transition towards systemic thinking and transformational change. In the interdisciplinary approach to water management, economics should play a central role. Economic assessment and analysis is important not only to estimate the economic costs and benefits of water related policies, but also to assess the preferences and the budget constraint of the individuals and of the society, that impact on the successful implementation of the WFD.

A related question that rises naturally regards the management measures, i.e. what water management measures would be cost-effective? Addressing this question and keeping in line with the WFD, requires a structured use of knowledge on the evaluation of water resources, 
on the estimation of the different costs and benefits for different water users and the environment and associated specific scenario(s) through appropriate socio-economic assessment.

As an overall recommendation, it is important to invest on a knowledge base on the socioeconomic valuation of the ecosystem services of water resources, which should be dynamically integrated in all steps of the assessment of respective programmes of measures and their revisions.

\section{GIRLS I ADD HERE SENTENCES THAT NEED TO BE INCLUDED IN THE CHAPTER. YOU CAN DECIDE WHERE TO PUT IT, MAIN TEXT/CONCLUSIONS}

The WFD embraces the polluter-pays-principle. The introduction of this principle stimulated growing interest in applying economic instruments. Through their application cost-effective management and innovation in pollution control technology, can be achieved. Economic or market-based instruments rely on market forces and changes in relative prices to modify the behaviour of public and private water users, in a way that supports environmental protection or improvement. The other main regulatory alternative is "command and control" that function through regulating processes or products, limiting the discharge of specified pollutants, and by restricting certain polluting activities to specific times or areas. An additional way to influence the behaviour of water users is through education and awareness campaigns, which may involve voluntary agreements to undertake pollution control measures.

Below we briefly introduce each of the min economic instruments available and used in water policy making. Marginal cost pricing, in the form of water tariffs and charges, can reduce excessive water use and pollution, as well as ensure the financial sustainability of water management plans. A pollution charge or tax can be defined as a "price" to be paid on the use of the environment. The four main types of charges used for controlling pollution are: (i) effluent charges, i.e. charges which are based on the quantity and/or quality of the discharged pollutants, (ii) user charges, i.e. fees paid for the use of collective treatment facilities, (iii) product charges, i.e. charges levied on products that are harmful to the environment when used as an input to the production process, consumed, or disposed of, and (iv) administrative charges, i.e. fees paid to authorities for such purposes as chemical registration or financing licensing and pollution control activities. Marketable permits are another market-based economic instrument, which can be implemented by an authority that can set the maximum limit on the total allowable extraction of water or emissions of a pollutant. It then allocates this total amount among the agents that extract or pollute by issuing permits that authorize specific amounts of abstraction or emissions over a specified period of time. After their initial distribution, permits can be bought and sold. Another instrument is subsidies, which translate in tax incentives (accelerated depreciation, partial expensing, investment tax credits, tax exemptions/deferrals), grants and low interest loans designed to induce polluters to reduce the quantity of their discharges or extraction, by investing in various types of pollution/abstraction control/reduction measures. The removal of a subsidy is another effective tool for controlling pollution. Deposit-refund systems, which entail consumers paying a surcharge when purchasing a potentially polluting product. When the product is returned to an approved centre for recycling or proper disposal, their deposit is refunded. 
Enforcement incentives are penalties designed to induce polluters/user of water to comply with environmental standards and regulations. They include non-compliance fees (i.e. fines) charged to polluters when their discharges exceed accepted levels, performance bonds (payments made to regulatory authorities before a potentially polluting activity is undertaken, and then returned when the environmental performance is proven to be acceptable), and liability assignment, which provides incentives to actual or potential polluters to protect the environment by making them liable for any damage they cause.

The main advantage of economic instruments is that they are incentive compatible (incentivize efficient technology adoption, economizing on water use, cost-effectiveness, etc.), while they have low enforcement costs and need minimum monitoring. However, in most cases, economic instruments supplement the existing regulatory framework. By selecting the right mix of regulatory and economic instruments, and in some cases other types of instruments such as property rights or educational approaches, policy makers can combine the positive elements of both approaches. The main advantage of the regulatory approach is that their effect on the reduction of pollution or abstraction is reasonably predictable. The major weaknesses of economic instruments are low predictability and that they require sophisticated institutions to implement and enforce them properly, particularly in the case of charges and tradable permits.

You can close the chapter by referring to multiple stressor and multiple socioeconomic instruments addressing each stressor, using the text above.

\section{I hope this helps}

\section{References}

Cooley, H., Ajami, N., Ha, M., Srinivasan, V., Morrison, J., Donnelly, K. \& Christian-Smith, J. (2013) .Global Water Governance in the $21^{\text {st }}$ Century. Pacific Institute: Oakland

European Environment Agency (2010) Scaling up ecosystem benefits — assessing largescale ecosystem services with primary data, EEA Technical Report 2010, Copenhagen

European Environment Agency (2014) River basin management plans and programme of measures [Online] Available: https://www.eea.europa.eu/themes/water/watermanagement/river-basin-management-plans-and-programme-of-measures (Accessed: 25/05/2017)

European Commission (1980) Council Directive 80/778/EEC [Online] Available: http://eurlex.europa.eu/LexUriServ/LexUriServ.do?uri=CONSLEG:1980L0778:19950101:EN:PDF (Accessed: 22/05/2017) 
European Commission (2002), 'EU Guidance Document: Economics and the Environment. The Implementation Challenge of the Water Framework Directive'[Online] Available: http://forum.europa.eu.int/Public/irc/env/wfd/library (Accessed: 25/05/2017)

European Commission (2007) : Towards Sustainable Water Management in the European Union. First stage in the implementation of the Water Framework Directive 2000/60/EC. SEC(2007) 362. EC: Brussels

European Commission (2017) The EU Water Framework Directive - integrated river basin management for Europe. [Online] Available:

http://ec.europa.eu/environment/water/water-framework/index_en.html (Accessed: $22 / 05 / 2017)$

Garrod, G., Willis, K. (1999). Economic Valuation of the Environment: Methods and Case Studies. Edward Elgar Publishing Ltd: Cheltenham

Gollier, C, Koundouri, P, Pantelidis, T. (2008). Declining discount rates: economic justifications and implications for long-run policy, Economic Policy, 23 (56), 758-795.

GRÜNEN LIGA e.V. (2011) Economic Instruments in the Water Framework Directive: An Opportunity for Water Protection Shortcomings in the First Management Cycle and the Need for Action. [Online] Available: http://www.wrrl-info.de/docs/brosch_en_web.pdf (Accessed: 25/05/2017)

Inter-Agency and Expert Group on SDG Indicators (2017) Report of the Inter-Agency and Expert Group on Sustainable Development Goal Indicators (E/CN.3/2017/2) [Online] Available: https://unstats.un.org/sdgs/indicators/Official\%20Revised\%20List\%20of\%20global\%20SDG \%20indicators.pdf (Accessed: 22/05/2017)

Joint Nature Conservation Committee (2010) Council Directive 2000/60/EC establishing a framework for Community action in the field of water policy (Water Framework Directive) [Online] Available: http://jncc.defra.gov.uk/page-1375 (Accessed: 25/05/2017) 
Kavanagh, P. \& Bree, T. (2009) Water Framework Directive Programme of Measures: Protection of high-status sites, forest, water and on-site wastewater treatment systems. Biology and Environment: Proceedings of the Royal Irish Academy. 109B(3), pp. 345-364

Koundouri, P. (2004). Current issues in the economics of groundwater resource management. Journal of Economic Surveys, 18 (5), pp. 703-740.

Koundouri, P. (2009). Editor's introduction, special issue on: discounting the long-run future and sustainable development. Econ. E-J., 3

Koundouri, P. \& Dávila, O. (2015). The use of the ecosystem services approach in guiding water valuation and management: Inland and coastal waters. Handbook of Water Economics, pp. 126-149.

Koundouri, P., Akinsete, E. \& Souliotis, I. (2017) H2020 GLOBAQUA Project Internal Report on Case Studies' Programmes of Measures. ICRE8: Athens

Koundouri, P., Ker Rault, P., Pergamalis, V., Skianis, V., Souliotis, i. (2016). Development of an integrated methodology for the sustainable environmental and socio-economic management of river ecosystems, Science of The Total Environment, 540(1), 90-100,.

Ludwig, R., Roson, R., Zografos, C., \& Kallis, G. (2011) Towards an inter-disciplinary research agenda on climate change, water and security in southern Europe and neighboring countries. Environmental Science and Policy, 14, pp.794-803.

Navarro-Ortega, A., Acuña, V., Bellin, A., Burek, P., Cassiani, G., Choukr-Allah, R., Dolédec, S., Elosegi, A., Ferrari, F., \& Ginebreda, A., et al., (2015) Managing the effects of multiple stressors on aquatic ecosystems under water scarcity. The GLOBAQUA project. Science of the Total Environment. 503, pp. 3-9.

Pearce, D., Atkinson, G. and Mourato, S. (2006). Cost-benefit analysis and the environment. Recent Developments, Organisation for Economic Co-operation and Development (2006)

Pistocchi, A., Udias, A., Grizzetti, B., Gelati, E,. Koundouri, P., Ludwig, R., Papandreou, A., Souliotis, I. (2016) An integrated assessment framework for the analysis of multiple pressures in aquatic ecosystems and the appraisal of management options. Science of the Total Environment. 575, pp. 1477-1488. 
Reynaud, A. (2015). Modelling Household Water Demand in Europe - Insights from a CrossCountry Econometric Analysis of EU-28 countries. JRC Technical report EUR 27310 EN, 2015.

van Rijswick, H.F.M.W. \& Backes, C.W., (2015) Ground breaking landmark case on environmental quality standards? Journal of European Environmental and Planning Law. 12, pp. 363-366.

Rogers, P. \& Hall, A. (2003) “Effective Water Governance. TEC Report No. 7”, Global Water Partnership, Stockholm.

Sustainable Development Solutions Network (2015) Indicators and a Monitoring Framework for the Sustainable Development Goals. New York: United Nations

TEEB, (2010) Pushpam Kumar (Ed.), The Economics of Ecosystems and Biodiversity Ecological and Economic Foundations, Earthscan, London

UN Water (2013) Water Quality. [Online] Available:

http://www.unwater.org/fileadmin/user_upload/unwater_new/docs/water_quality.pdf (Accessed: 22/05/2017)

United Nations (2016) Sustainable Development Goals. [Online] Available: https://sustainabledevelopment.un.org/sdgs (Accessed: 26/9/16)

Venkatachalam, L. (2004). The contingent valuation method: a review. Environmental Impact Assessment Review, 24 (1), 89-124.

Vörösmarty, C.J., McIntyre, P.B., Gessner, M.O., Dudgeon, D., Prusevich, A., \& Green, P., et al. (2010) Global threats to human water security and river biodiversity. Nature. 467, pp. $555-561$.

Voulvoulis, N., Arpon, K.D., \& Giakoumis, T. (2017) The EU Water Framework Directive: From great expectations to problems with implementation. Science of the Total Environment. 575, pp. 358-366. 
WWF (2004) Tips and Tricks for Water Framework Directive Implementation. [Online] Available: http://www.rivernet.org/general/docs/200403_EEB_WWF_Tips\&Tricks.pdf (Accessed: 25/05/2017) 


\section{Acknowledgements}

This work has been supported by the European Communities $7^{\text {th }}$ Framework Programme Funding under Grant agreement no. 603629-ENV-2013-6.2.1-Globaqua and by the EU Framework Programme for Research and Innovation, Horizon 2020, Funding under Grant agreement no. 690268-2-WATER-5c-2015-DAFNE. 